\title{
STUDY OF THE IMPACT OF TRAINING OF NOVICE TEACHERS IN THE CONTEXT OF TRANSFORMATIVE LEARNING IN PUNJAB, PAKISTAN
}

\author{
Muhammad Azhar \\ Department of Education, International Islamic University, Islamabad, Pakistan \\ drazhariiui@gmail.com \\ Muhammad Munir Kayani \\ Chairman, Department of Education, International Islamic University, Islamabad, Pakistan \\ drmunirkayani@yahoo.com
}

\begin{abstract}
Transformation learning theory explains transformative learning and the mechanism of its occurrence. The objectives of the study were to evaluate the professional development of novice teachers in the area of classroom practices, teaching methodology and lesson planning in the context of transformative learning and to explore transformative learning among novice teachers manifesting in classrooms with respect to their designations and academic qualifications. The study used quantitative survey research design. A number of 78092 teachers who were recruited in three years across Punjab, Pakistan (2010, 2011 and 2012) were selected as target population of the study. Out of them, 1036 novice teachers were randomly selected as a sample of the study. A questionnaire was used for the collection of data. The data were analysed by one-way ANOVA and independent Post Hoc Tukey test. It was found that a change occurred in classroom practices of novice teachers. Our study has shown that there were differences among novice teachers with respect to the designation and qualification of novice teachers in the area of classroom practices. The study recommended for school education department to introduce latest classroom practices to other tiers of teachers and to develop an implementation strategy for professional development programmes.
\end{abstract}

Keywords: novice teachers; teacher training; lesson planning skills; classroom observation.

\section{Introduction}

Comparatively less investment in education than other government departments, insufficient literacy rate, low quality of education, war on terror and low capacity of teachers are the main issues of education in Pakistan. These issues hinder the quality of education in Pakistan and especially in province Punjab. Hence it is a dire need to meet these challenges. Teachers are considered as the backbone of an education system. Teaching effectiveness depends on many factors like, teachers' knowledge about the subject, teaching skills and their professional development. The most important in this regard is the professional development. Teaching skills required for effective classroom management can be enhanced through different training programmes. It is the professional development which equips the workers with the skills essential for better outcomes (Silberman \& Auerbach, 2006). It is a process that continues throughout the life and man keeps on learning with every new experience (Cowley, 2013). Self-reliance and problem-solving skills can help the teachers independent of mentor assistance (Brock \& Grady, 2006). Teacher role is multidimensional to improve the overall education system. Teaching skills required for effective classroom management can be enhanced through different programmes. Student's higher achievements are possible only due to teachers' in-service trainings (Rao, 2011). Therefore, the aim of training should improve the professional aspects of teachers. Teacher educators should actively focus on enhancing their characteristics among the trainee teachers (Brookfield, 1995).

The transformation theory deals with changing a qualified individual to a skilled worker (Mezirow, 2000b). Professional development opportunities do facilitate the perspective transformation.(King, 2002) The use of transformative learning in educational setting carries higher education as its example (Barlas, 2001; Glisczinski, 2007; Gravett, 2004). It also includes cooperate human resources development (Hsiao \& Chang, 2011), academic committees(Kokkos, 2010), community education(Silverman, 2004) and professional development for teachers (Griswold, 2007; McQuiggan, 2006).

In order to transfer the novice teachers to skilled teachers, the Directorate of Staff Development (DSD) kept on working with a vision of developing such cadre of teacher which would be highly knowledgeable, full of commitment, motivated and ethically sound. The aim was to promote quality education in the public schools of Punjab and producing individuals for better social and economic setup (Govt. of Punjab, 2009).

Induction professional development was made mandatory for novice teachers in Punjab by the recommendations of teacher education task force Punjab in 2009. This led the DSD to organise a four-week programme for professional development of 78092 educators recruited during the years 2010, 2011 and 2012 in the Punjab education department. Training modules were specially prepared for the professional development of novice teachers. These modules included material related to professional development in the area of lesson planning, classroom practices, teaching methodologies, conceptual teaching, activities, 
educational technology, service related rules and government initiatives. This programme focused on enhancing the capability of novice teachers.

It is always necessary to evaluate the effectiveness of training and professional development process. Critical analysis and researches are made to analyse objectives, methodology, utility and impact of professional development programmes. On behalf of the research outcomes, one can decide to what extent objectives were achieved? What innovations were introduced? Above mentioned professional development programme for novice teachers was interesting and unique as first time in the history of the Punjab, Pakistan. Novice teachers were equipped with latest techniques of teaching. So it was interesting for researchers to evaluate this professional development programme.

Our research presents a unique examination of transformation experiences and their nature in the process of professional development. It has been recognised that the educational process may lead to transformational learning and the nature of change could be examined. We evaluated professional development programme for novice teachers in the context of transformative learning organised by Directorate of Staff Development (DSD), Punjab, Pakistan. This programme has focused on lesson planning skills, classroom practice and teaching methodologies used by novice teachers with respect to trained teachers. Furthermore, This study was also aimed to evaluate the improvement in classroom practices of novice teachers through transformative learning.

\section{Methods}

\subsection{Study Population}

Induction professional development was made mandatory for novice teachers in Punjab, Pakistan with the recommendations of Teacher Education Task Force Punjab (TETFP) in 2009. This led the Directorate of Staff Development (DSD) to organise a four-week programme for professional development of 78092 educators recruited during the years 2010, 2011 and 2012 in Punjab, Pakistan education department. These educators were recruited as elementary school educators, senior elementary school educators and secondary school educators (Govt. of Punjab, Pakistan, 2012). Those all 78092 novice teachers were our study targeted population.

\subsection{Sample Selection}

For a selection of the sample, multistage sampling technique was used. In the first stage, we studied 8 districts out of 36 districts of Punjab, Pakistan, where the number of total inducted teachers per district was more than 1500 who participated in the professional development programme (Fig 1). In the second stage, from every stratum of novice Elementary, Senior Elementary and Secondary School Educators of selected districts, $5 \%$ of each stratum were randomly selected as sample of study making a number of 1036 novice teachers (Fig.1b). According to Gay et al., (2000), if the population size is 78000 then the sample size should be 382, but we took a sample size more than this proposed number (Gay, Mills, \& Airasian, 2012). Inclusion criteria were limited to Elementary School Educators, Senior Elementary School Educators and Secondary School Educators who were recruited in recruited in the years 2010, 2011 and 2012 and were imparted fourweek induction training by DSD, Punjab, Pakistan.
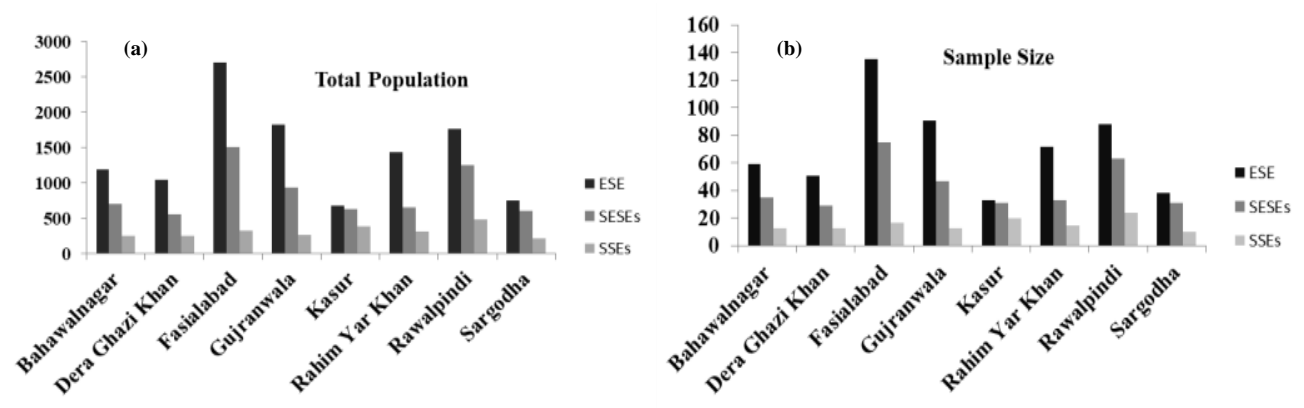

Fig1. (a) Total Population of Novice teachers in 8 districts, (b) Randomly selected sample size

\subsection{Research Methodology}

Quantitative data were collected from novice teachers through a structured questionnaire to gain information about transformation in novice teachers in the area of lesson planning, teaching methodology and classroom practices. Observations were made to find out transformations among novice teachers manifesting in classrooms. Quantitative data were analysed in the lights of objectives. The post-positivist worldview was used for the study of professional development of novice teachers in the context of transformative learning in Punjab, Pakistan. The questionnaire was based on a five-point Likert scale; 
Strongly Agree (SA), Agree (A), Undecided (UD), Disagree (DA), Strongly Disagree (SDA) for the novice teachers included in the sample of the study to evaluate the professional development in the context of Transformative learning. This questionnaire was filled in by the novice teachers included in the sample size. A self-designed observation checklist based on 3 points Guttman scale Yes, To Some Extent, No was used to find out transformation among novice teachers by observing them in classrooms.

The point value was assigned to responses of positive statement of questionnaire according to scale of $\mathrm{SA}=5, \mathrm{~A}=4, \mathrm{UD}=3, \mathrm{DA}=2, \mathrm{SDA}=1$. While for negative statement of questionnaire, point values were reversed that were $\mathrm{SA}=1, \mathrm{~A}=2, \mathrm{UD}=3, \mathrm{DA}=4, \mathrm{SDA}=5$.

\subsection{Statistical Analysis}

The statistical technique one way ANOVA and an independent sample $t$ test at significance level of 0.05 were done by using SPSS version 18 (SPSS Inc., Chicago, IL, USA) to analyse the quantitative data collected through questionnaires One way ANOVA was used at significance level of 0.05 to find significant difference in the mean scores of novice teachers regarding professional development in the area of lesson planning skills, classroom practices and teaching methodologies in the context of transformative learning with respect to their designation and academic qualification. An independent Post Hoc Tukey test was used at significance level of 0.05 to find a significant difference in the mean scores of lesson planning skills, teaching methodology and classroom practices in the context of transformative learning with respect to the professional qualification of novice teachers.

\section{Results}

\subsection{Overall Impact}

At the first place we measured the overall impact of training at three main parameters of teacher's training which were lesson plan, teaching methodology and classroom practice. Table 1 shows descriptive statistics related to total professional development score. According to results the total lesson plan scores $(\mathrm{M}=61.3290, \mathrm{SD}=4.49630, \mathrm{Min}=44, \mathrm{Max}=70)$, teaching methodology scores $(\mathrm{M}=74.5884, \mathrm{SD}=6.04933$, Min= 48, Max=85), total classroom practice scores $(M=84.6227, S D=6.62023$, Min= 56, Max=95) has skewness and kurtosis ranging between -2 to +2 . This shows that the data has been normally distributed. Comparison of the mean scores showed that lesson plans had the lowest mean score value that was 61.3290 while the mean score value of teaching methodology was 74.5884 which was better one and classroom practices had the highest mean score value which was 84.6227. Our study results depicted that novice teachers showed better development in terms of teaching methodology and classroom practices.

Table 1

Descriptive Statistics Related to Total Professional Development Scores

\begin{tabular}{cccccccc}
\hline Total Scores & N & Min. & Max & Mean & SD & Skewness & Kurtosis \\
\hline Lesson Plan & 933 & 44.0 & 70 & 61.3290 & 4.4963 & -.434 & .168 \\
$\begin{array}{c}\text { Teaching } \\
\text { methodology }\end{array}$ & 933 & 48.0 & 85 & 74.5884 & 6.0493 & -.437 & .464 \\
$\begin{array}{c}\text { Classroom } \\
\text { Practice }\end{array}$ & 933 & 56.0 & 95 & 84.6227 & 6.6202 & -.572 & .311 \\
\hline
\end{tabular}

\subsection{Impact w.r.t Designation of Novice Teachers}

\subsubsection{Lesson Planning Skills}

In the second phase, we compared the impact of training among teachers on the basis of their designations. Our results are shown in Table 2. It was found that there was no significant difference in the mean scores of Elementary, Senior Elementary and Secondary School novice teachers regarding professional development of lesson planning skills in the context of transformative learning $(F(2,930)=.734, p=.480)$.

As lesson planning is a basic skill for teachers to learn and every teacher needs to have command over it. Data analysis showed that Elementary, Senior Elementary and Secondary School novice teachers benefitted equally from professional development programmes in the area of lesson planning skills in context of transformative learning. Gibs and Coffey (2004) have also given a positive result of professional development programmes for teachers.

Table 2

Total Lesson Plan scores w.r.t. Designation of Novice Teachers

\begin{tabular}{cccc}
\hline & $\boldsymbol{d} \boldsymbol{f}$ & $\boldsymbol{F}$ & $\boldsymbol{p}$ \\
\hline Between Groups & 2 & .734 & .480 \\
Within Groups & 930 & & \\
Total & 932 & & \\
\hline
\end{tabular}




\subsubsection{Classroom Practices}

It has been found that there is a significant difference in classroom practice of novice teachers. Table 3 shows that there was a significant difference in the mean scores of Elementary, Senior Elementary and Secondary School novice teachers regarding professional development of classroom practices in context of transformative learning $(F(2,930)=5.741, p=.003)$.

As there was a significant difference between groups so Post Hoc Tukey Test was applied (Table 4). Results showed that there was a significant difference in the mean scores of ESE $(M=85.243, S D=6.526)$ and SESE ( $M=84.0871, S D=6.666)$ regarding classroom practices $(p=0.39)$. Moreover, there was a significant difference in the mean scores of ESE $(M=85.243, S D=6.526)$ and SSE $(M=83.236, S D=6.644),(p=0.01)$. But there was no significant difference in the mean scores of SESE (M=84.0871, SD=6.666) and SSE $(\mathrm{M}=83.236, \mathrm{SD}=6.644),(p=0.475)$.

Classroom practices help teachers to perform activities and creating a positive classroom environment. Master trainers need to focus each and every participant while imparting trainings. Better performance of Elementary school teachers than Senior Elementary and Secondary School novice teachers regarding professional development of classroom practices in the context of transformative learning shows that continuous professional development programme of DSD is positively affecting the efficiency of Elementary school teachers. Gao and Wang (2014) has also concluded that different teaching experiences shape the teaching practices in different ways (Gao \& Wang, 2014).

Table 3

Total Classroom Practice Score w.r.t. Designation of Novice Teachers

\begin{tabular}{cccc}
\hline & $\boldsymbol{d} \boldsymbol{f}$ & $\boldsymbol{F}$ & $\boldsymbol{p}$ \\
\hline Between Groups & 2 & 5.741 & .003 \\
Within Groups & 930 & & \\
Total & 932 & & \\
\hline
\end{tabular}

Table 4

Analysis of Total Classroom Practice Score with Tukey HSD

\begin{tabular}{ccc}
\hline Designation & Designation & $\boldsymbol{p}$ \\
\hline ESE & SESE & .039 \\
& SSE & .011 \\
\hline SESE & ESE & .039 \\
& SSE & .475 \\
\hline SSE & ESE & .011 \\
& SESE & .475 \\
\hline
\end{tabular}

\subsubsection{Teaching Methodology}

As teaching methodology is a key trait of successful teacher, it is an art of expressing your knowledge and information in an interesting way to student. Therefore, we also evaluate teaching methodology of novice teachers. Table 5 shows that there was no significant difference in the mean scores of Elementary, Senior Elementary and Secondary School novice teachers regarding professional development of teaching methodology in context of transformative learning $(F(2,930)=0.600, p=0.549)$.

Table 5

Total Teaching Methodology Scores w.r.t. Designation of Novice Teachers

\begin{tabular}{cccc}
\hline & $\boldsymbol{D} \boldsymbol{f}$ & $\boldsymbol{F}$ & $\boldsymbol{p}$ \\
\hline Between Groups & 2 & .600 & .549 \\
Within Groups & 930 & & \\
Total & 932 & & \\
\hline
\end{tabular}

Innovative teaching methodologies bring an innovation in the classroom and make teaching more useful and interesting. Data analysis showed that Elementary, Senior Elementary and Secondary School novice teachers benefitted equally from professional development programmes in the area of teaching methodology in context of transformative learning. It was also asserted by Kasl and Elias (2000) that innovative teaching methodologies and group activities enabled transformative learning (Mezirow, 2000a). 


\subsection{Impact on Training w.r.t to Academic Qualification}

\subsubsection{Lesson Planning Skills}

The design of the course and making plan to deliver lesson is vital for teaching process. In our study, we compared the effect of training in lesson planning skills of novice teachers with respect to transformative learning according to their basic qualifications and results are shown in Table 6.

These results showed that there was a significant difference in the mean scores of lesson planning skills in the context of transformative learning with respect to academic qualification of novice teachers. $(F(2,930)$ $=3.183, p=0.042$ ). Significant difference between groups was observed, so we applied Post Hoc Tukey Test and the results are shown in Table 6. It was found that there was a significant difference in the mean scores of lesson planning skills of Bachelor $(\mathrm{M}=61.8116, \mathrm{SD}=4.321)$ and Master degree holders $(\mathrm{M}=61.0564$, $\mathrm{SD}=4.608)(p=0.040)$. But there was no significant difference in the mean scores of Bachelor $(\mathrm{M}=61.8116$, $\mathrm{SD}=4.321)$ and $\mathrm{M}$ Phil degree holders $(\mathrm{M}=60.946, \mathrm{SD}=4.295),(p=.374)$. There was also no significant difference in the mean scores of Master $(M=61.0564, S D=4.608)$ and $M$ Phil degree holders $(M=60.946$, $\mathrm{SD}=4.295),(p=.983)$. (Table 7)

Table 6

ANOVA of Total Lesson Plan Scores w.r.t. Academic qualification

\begin{tabular}{cccc}
\hline & $\boldsymbol{D} \boldsymbol{f}$ & $\boldsymbol{F}$ & $\boldsymbol{p}$ \\
\hline Between Groups & 2 & 3.183 & .042 \\
Within Groups & 930 & & \\
Total & 932 & & \\
\hline
\end{tabular}

Table 7

Multiple Comparisons of total lesson plan Scores w.r.t. academic qualification with Tuky HSD

\begin{tabular}{ccc}
\hline Academic Qualification & Academic Qualification & $\boldsymbol{p}$ \\
\hline Bachelor & Master & .040 \\
& M.Phil. & .374 \\
\hline Master & Bachelor & .040 \\
& M.Phil. & .983 \\
\hline M.Phil. & Bachelor & .374 \\
& Master & .983 \\
\hline
\end{tabular}

A teacher being less or more qualified needs to have mastery in lesson planning skills. As Bachelor degree holders teach at primary level and they are being provided professional support by District Teacher Educators so their performance is better than Master degree holders. It seems the effect of the continuous professional development programme of DSD for primary school teachers that Bachelor degree holder elementary school educators were performing better then master degree holders.

\subsubsection{Class Room Practice}

Table 8 shows that there is a significant difference in the mean scores of classroom practices in the context of transformative learning with respect to academic qualification of novice teachers $(\mathrm{F}(2,930)=$ 8.343, $\mathrm{p}=0.000$ ). Significant difference between groups was noticed, so we applied Post Hoc Tukey Test. Table 9 shows a significant difference in classroom practices of Bachelor $(\mathrm{M}=61.8116, \mathrm{SD}=4.321)$ and Master degree holders $(\mathrm{M}=61.0564, \mathrm{SD}=4.608),(p=0.002)$. There was also a significant difference in the mean scores of Bachelor $(M=61.8116, S D=4.321)$ and $M$ Phil degree holders $(M=60.946, S D=4.295)$, $(p=.006)$. There was no significant difference in the mean scores of Master $(\mathrm{M}=61.0564, \mathrm{SD}=4.608)$ and M Phil degree holders ( $\mathrm{M}=60.946, \mathrm{SD}=4.295),(p=0.306)$.

Table 8

Total Classroom Practices Scores w.r.t Academic Qualification

\begin{tabular}{cccc}
\hline & $\boldsymbol{D} \boldsymbol{f}$ & $\boldsymbol{F}$ & $\boldsymbol{p}$ \\
\hline Between Groups & 2 & 8.343 & .000 \\
Within Groups & 930 & & \\
Total & 932 & & \\
\hline
\end{tabular}


Multiple Comparisons of Total Classroom Practices Scores w.r.t. Academic Qualification with Tukey HSD

\begin{tabular}{ccc}
\hline Academic Qualification & Academic Qualification & $\boldsymbol{p}$ \\
\hline Bachelor & Master & .002 \\
& M.Phil. & .006 \\
\hline Master & Bachelor & .002 \\
& M.Phil. & .306 \\
\hline M. Phil. & Bachelor & .006 \\
& Master & .306 \\
\hline
\end{tabular}

Latest classroom practices motivate learners and give a better output. Bachelor degree holders were performing better in the area of classroom practices. It has been discussed earlier that bachelor degree holders teach at primary level and they are being provided with professional support by District Teacher Educators. It also seems the mentoring effect of the continuous professional development programme of DSD that primary school teachers were performing better comparatively.

\subsubsection{Teaching Methodology}

Table 5 shows that there is no significant difference in the mean scores of teaching methodology in context of transformative learning with respect to academic qualification of novice teachers $(F(2,930)=$ $2.449, p=0.087)$.

Teaching methodologies play vital role in teaching learning process. Use of the best and latest teaching methodologies enhances the capacity of teachers. Data analysis showed that Elementary, Senior Elementary and Secondary School novice teachers benefitted equally from professional development programmes in the area of teaching methodology in context of transformative learning.

\section{Discussion}

The standard of teaching process and education quality, mainly depends on the ability, commitment and skills of the teacher. The teacher is a key to success of the whole process of education. If the teacher is not capable of imparting instructions properly and he does not keep himself up to date with modern, innovative skills and current information in his area of specialisation then he becomes less efficient and less productive as it is indicated in the National Education Policy of Pakistan (1998-2010, p0.47). Professional skills and knowledge of a teacher can be improved through training and development process. Training is an important part of teacher preparation programmes, especially for those aspects of teaching that are more skill-like in their conception, but there are many other important aspects of teaching that can only be nurtured through reflective strategies and experiences. Training teachers is more likely to lead to diversity in practice at all levels of instruction.

The effectiveness of pedagogical training of teachers in school education was studied by many researchers with different results. The present research has reached the conclusion that the performance of novice teachers has positively been affected through professional development (Gibbs \& Coffey, 2004). Our study showed positive results of these training programmes on the effectiveness of teachers. Using the approaches to teaching inventory, they presented that in the four-month programme, the approach shifted from teacher-centred to student-centred. We also found that academic teaching was also positively influenced by these trainings. It was, however, found by Postareff et al. (2007) that these transformations were gradual. Teachers' pre-service trainings were found not necessarily related to their productivity (Harris \& Sass, 2011; Postareff, Lindblom-Ylänne, \& Nevgi, 2008). The effective use of up-to-date technology was studied by Galien and Bowcher (2010) in a well-informed curriculum (Patricia Galien., 2010). These experiences do carry the effect of school cultures of teaching interacted with the centralised curriculum and teaching community. Thus, there were various effects of training on teachers depending upon their social and cultural circumstances of learning (Kemmis, Hannu, Heikkinen and Aspfors, 2014). The findings of the study conducted by Consuegra, Engels and Struyven (2014) pointed out that the schools tended not to facilitate the purpose of workplace learning (Consuegra, Engels, \& Struyven, 2014). They instead hinder it. The teacher with pre-service training resulted in higher student achievement. Molding, Stewart \& Dunmeyer (2014), Stuckey \& Taylor (2000), Moulding, Stewart, \& Dunmeyer (2014), and Taylor (2012) worked together developing the inclusive evaluation of transformative learning theory. The population of the study was the college teachers. The theory encompassed various perceptions of transformative learning. 
In this study, the novice teachers were questioned regarding the use of classroom practices to find transformation in this regard. It was revealed that classroom practices introduced by the master trainer were proficiently adopted by the novice teachers.

Classroom practices help teachers to perform activities and creating a positive classroom environment. Master trainers need to focus each and every participant while imparting training. Better performance of Elementary school teachers than Senior Elementary and Secondary School novice teachers regarding professional development of classroom practices in the context of transformative learning shows that continuous professional development programme of DSD is positively affecting the efficiency of Elementary school teachers in Punjab, Pakistan. In this programme, Elementary school teachers are provided on-site professional support by mentors. We found that teacher training programme is a key factor in their professional development. Gao and Wang (2014) concluded that different teaching experiences shape the teaching practices in different ways (Gao \& Wang, 2014).

\section{Conclusions}

Our study shows that overall novice teachers demonstrate better development in terms of teaching methodology and classroom practices as compared to lesson planning skills. Further, it was found that elementary school educators were performing better than senior elementary school educators and secondary school educators in the context of classroom practices. Moreover, Bachelor degree holder novice teachers were performing better than Master degree holders in the area of classroom practices. Bachelor degree holder novice teachers were also performing better than M Phil degree holder novice teachers in the area of classroom practices. Novice teachers implemented classroom practices successfully. It is recommended for school education department to introduce latest classroom practices to other tiers of teachers. Keeping in view the outcomes of our study, we would like to recommend training modules provided activities for transformative learning to novice teachers. It is also recommended for the DSD to prepare such type of modules having literature in the areas of lesson planning skills, classroom practices and teaching methodologies for other practising teachers. Additionally, we also suggest that incentives may be given to novice teachers for successful participation in trainings and its implementations.

\section{Conflict of Interest}

Authors have no conflict of interests.

\section{Funding Source}

This study was supported by Higher Education Commission (HEC), Pakistan under PhD Indigenous Scholarship Programme Phase (IV).

\section{References:}

Barlas, C. (2001). Learning-within-Relationship as Context and Process in Adult Education : Impact on Transformative Learning and Social Change Agency. Adult Education Research Conference 2001 Proceeding, 2 . Retrieved 22 August, 2017 from https://www.unicef.org/pakistan/overview_5070.html

Brock, B. L., \& Grady, M. L. (2006). Developing a teacher induction plan : a guide for school leaders. Thousand Oaks, CA: Corwin Press. Brookfield, S. (1995). Becoming a critically reflective teacher. San Francisco: Jossey-Bass.

Consuegra, E., Engels, N., \& Struyven, K. (2014). Beginning teachers' experience of the workplace learning environment in alternative teacher certification programs: A mixed methods approach. Teaching and Teacher Education, 42, 79-88. https://doi.org/10.1016/j.tate.2014.05.001

Cowley, S. (2013). How to survive your first year in teaching. Edinburgh: Continuum.

Gao, S., \& Wang, J. (2014). Teaching transformation under centralized curriculum and teacher learning community: Two Chinese chemistry teachers' experiences in developing inquiry-based instruction. Teaching and Teacher Education, 44, 1-11. https://doi.org/10.1016/j.tate.2014.07.008

Gay, L. R., Mills, G. E., \& Airasian, P. W. (2012). Educational research : competencies for analysis and applications. New York: Pearson.

Gibbs, G., \& Coffey, M. (2004). The Impact Of Training Of University Teachers on their Teaching Skills, their Approach to Teaching and the Approach to Learning of their Students. Active Learning in Higher Education, 5(1), 87-100. https://doi.org/10.1177/1469787404040463

Glisczinski, D. J. (2007). Transformative Higher Education. Journal of Transformative Education, 5(4), 317-328. https://doi.org/10.1177/1541344607312838

Gravett, S. (2004). Action research and transformative learning in teaching environment. Educational Action Research, 12 (August), 259-272. https://doi.org/10.1080/09650790400200248

Griswold, W. (2007). Transformative learning in a post-totalitarian context: professional development among school teachers in rural Siberia. Kansas State University. Retrieved 22 August, 2017 from http://krex.k-state.edu/dspace/handle/2097/454

Harris, D. N., \& Sass, T. R. (2011). Teacher training, teacher quality and student achievement. Journal of Public Economics, 95(78), 798-812. https://doi.org/10.1016/j.jpubeco.2010.11.009

Hsiao, H.-C., \& Chang, J.-C. (2011). The role of organizational learning in transformational leadership and organizational innovation. Asia Pacific Education Review, 12(4), 621-631. https://doi.org/10.1007/s12564-011-9165-X

King, K. P. (2002). Keeping pace with technology : educational technology that transforms. Hangzhou: Hampton Press. 
Kokkos, A. (2010). Transformative Learning Through Aesthetic Experience. Journal of Transformative Education, 8(3), $155-177$. https://doi.org/10.1177/1541344610397663

McQuiggan, C. (2006). Teaching with New Eyes: Transformative Faculty Professional Development for Online Teaching. Adulterc.Org, 226-232. Retrieved 22 August, 2017 from http://www.adulterc.org/Proceedings/2012/papers/mcquiggan.pdf

Mezirow, J. (2000a). Learning as transformation : critical perspectives on a theory in progress. Washington, D.C: Jossey-Bass.

Mezirow, J. (2000b). Learning to think like an adult core concepts of transformation theroy. San Francisco.

Moulding, L. R., Stewart, P. W., \& Dunmeyer, M. L. (2014). Pre-service teachers' sense of efficacy: Relationship to academic ability, student teaching placement characteristics, and mentor support. Teaching and Teacher Education, 41, 60-66. https://doi.org/10.1016/j.tate.2014.03.007

Patricia Galien., W. L. B. (2010). Using Blogs in ESL/EFL Teaching and Teacher-Training. Asian EFL Journal. Professional Teaching Articles, 42, 4-23. https://doi.org/10.1007/s002489900087

Postareff, L., Lindblom-Ylänne, S., \& Nevgi, A. (2008). A follow-up study of the effect of pedagogical training on teaching in higher education. Higher Education, 56(1), 29-43. https://doi.org/10.1007/s10734-007-9087-z

Rao, D. B. (2011). Encyclopaedia of education for all (3 vols. set). New Dehli, India: Discovery Publishing Pvt.

Silberman, M. L., \& Auerbach, C. (2006). Active training: a handbook of techniques, designs, case examples, and tips. San Francisco: Pfeiffer.

Silverman, M. (2004). Community learning in environmental NGO projects in Vietnam: A comparative study. University of Southern California. Retrieved 22 August, 2017 from http://digitallibrary.usc.edu/cdm/compoundobject/collection/p15799coll16/id/334209

Stephen Kemmis, Hannu L.T. Heikkinen, Goran Fransson Jessica Aspfors, C. E.-G. (2014). Mentoring of new teachers as a contested practice: Supervision support and collaborative self development. Teaching and Teacher Education, 43, 154-164. https://doi.org/10.1099/jmm.0.012468-0

Taylor, E. W. P. C. (2012). A Content Analysis of Transformative Learning Theory, 333-339. Livermore: California.

UNICEF. (2008). Child Friendly School in Punjab Pakistan. Retrieved 22 August, 2017 from https://www.unicef.org/pakistan/overvi ew_5070.html on.

Received: October, 22, 2017

Accepted: December, 05, 2017 